Биљана Марић

Универзитет у Београду

Филолошки факултет

Катедра за славистику

biljanav@mail.ru

\section{Драгана Керкез}

Универзитет у Београду

Филолошки факултет

Катедра за славистику

draganakerkez@hotmail.com
УДК 37.016:811.161.1(497.11)

https://doi.org/10.18485/slavistika.2018.22.2.12

оригинални научни рад

примљено 04.03.2018.

прихваћено за штампу 04.10.2018.

\title{
ЧОВЕК У ОГЛЕДАЛУ ЈЕЗИКА У РУСКОМ И СРПСКОМ: НОВИ ИЗБОРНИ ПРЕДМЕТ НА КАТЕДРИ ЗА СЛАВИСТИКУ
}

У раду се даје теоријско и практично утемељење новог изборног предмета на Катедри за славистику Филолошког факултета Универзитета у Београду, заснованог на антропоцентрички конципираним лингвистичким правцима, на истраживањима тзв. језичке слике света. На конкретним примерима из творбе речи, морфологије, лексике и синтаксе илуструје се потреба за једним оваквим приступом учењу језика (превасходно на вишим нивоима образовања). Аутори свој приступ баштине и у конфронтативним проучавањима руског и српског језика у нашој средини. С методичког становишта предмет би требало да има веома позитивну мотивациону улогу, да допринесе бољем сагледавању „свога“ у контексту „туђег“.

Кључне речи: антропоцентризам, лингвистика, језичка слика света, изборни предмет, руски језик, српски језик.

This paper analyses both the theoretical and practical foundations of a new elective course at the Department of Slavic Studies at the Faculty of Philology, University of Belgrade. This course is based on anthropocentric approaches to language, on the study of the so-called language picture of the world. The need for such an approach to language study (foremost at the higher level of education) is illustrated through concrete examples from derivation, morphology, lexis and syntax. From the methodological point of view this course should have a very positive motivational role as well as contribute to the better understanding of «our own» in the context of «someone else's».

Key words: anthropocentrism, linguistics, language picture of the world, elective course, Russian language, Serbian language.

0. У лингвистичкој литератури друге половине 20. века (Апресян 1995; Арутюнова 1999; Яковлева 1994; Караулов 2010; Норман 2013; Шмелев 2002 и др.) доследно се скреће пажња на чињеницу да је за науку о језику од тог времена постала карактеристична оријентација на антропоцентричку парадигму (тј. да се у фокусу лингвистичких истраживања нашао човек, његов унутрашњи свет и његово понашање) $)^{1}$.

Суштина антропоцентризма у лингвистици је, како примећује J. С. Кубрјакова, у томе што се научни објекти изучавају пре свега из аспекта њихове улоге за човека (Кубрякова 1995). Такав приступ је био сам по себи неминован, по мишљењу Н. Д. Арутјунове, ако се пође од чињенице да је антропоцентричност

${ }^{1}$ И премда овакав приступ има своје утемељење у лингвистичкој мисли В. Хумболта, свој процват је добио тек у другој половини прошлог века. Како у свету, тако и код нас.

Славистика XXII/2 (2018) 
онтолошка црта језика: човек је у језику и кроз језик фиксирао свој физички изглед, своје емоције, свој интелект, своју перцепцију предметног и непредметног света (Арутюнова 1999).

Управо овај и овакав приступ који језик посматра као продукт човекове концептуализације стварности која га окружује јесте quinta essentia новог изборног предмета на Катедри за славистику Филолошког факултета у Београду.

Циљ овог рада је да у основним цртама аргументује неопходност овог предмета на филолошким студијама, те да у основним цртама пружи увид у његово теоријско-методолошко утемељење.

Рад који представљамо на увид научној јавности структурно чине два дела. У првом делу, на неколико примера (из творбе речи, морфологије именских речи, лексике и синтаксе), указаћемо на неке од проблема изучавања страног језика (конкретно, руског у српској говорној средини) који могу бити адекватно објашњени једино помоћу приступа чије теоријско утемељење чини језичка дисциплина експлицитније оријентисана ка човеку и његовом свету.

У другом делу рада покушаћемо што сажетије, али и довољно информативно упутити читаоце у теоријски (теоријско-методолошки) оквир предмета под називом „Човек у огледалу језика у руском и српском” тако што ћемо представити нека од најважнијих истраживања која чине основ теоријског дела наставе датог предмета.

1.1. Први део рада започећемо цитатом из збирке прича и есеја „Легкие миры“ (Лаки светови) савремене руске списатељице Татјане Толстој, која овако пише о употреби деминутива у руском свакодневном говору.

Они (уменьшительные суффиксы) - прекрасный инструмент, с помощью которого можно передать много оттенков смысла и настроения. Просто ими надо управлять, а не пугаться.

- Морковочки положить? Хлебиа? Колбаску кушайте, - это вот все правильно. Так надо, так угощают, так говорят за столом, словами выстраивая защитный колпак, купол над людьми, севщими за трапезу (...). Слова подают сигнал: тут мирно, тут спокойно, уютно, как в детстве; расслабьтесь.

Вы же не будете говорить: «Ешьте морковь». Она же колом в горле встанет.

Вот жена мужу говорит в магазине: «Какой сырик купим?» Это она не к сырику любовь испытывает, это она воркует с мужем, с его непредсказуемым настроением (...). А вдруг он будет туча тучей? А вдруг его мысли далеко, не с ней вот сейчас? Суффиксы задабривания, обещания, доверия-вот что такое эти «пищевые уменьшительные».

Винио и водочка. Селедочка под свеколкой. Карточечка. (С сольиой.) И с лучком. Маслище, особенно маслице. Колбасынька. Яичечко. Сырик. На хлебуике. Потом чаёк.

И спатеньки (Толстая 2014).

Није ли све ово што списатељица пише, интуитивно доживљавајући свој матерњи језик, средство уз помоћ ког ствара своја животна дела (па га због тога још интензивније и осећа од просечног говорника), добар део онога што настав- 
ник, обрађујући деминутиве из творбе речи или бавећи се превођењем са руског на српски треба да помене приликом објашњавања ове творбене категорије речи? Иако се чини да потпуну или блиску потпуној компетенцију у овладавању овим материјалом ученик може да стекне тек на вишим нивоима учења језика, сматрамо да би се и на нижим нивоима, у школи могла обраћати већа пажња на то својство руског језика и Руса: својеврсну љубав према деминутивима.

Овај пример смо одабрали из следећег разлога: дата творбена категорија (деминутива и хипокористика) тесно је повезана са категоријом емоција и блиској joj експресивности, што је чини снажно национално маркираном, будући да су емотивно-евалуативна значења нужно детерминисана менталитетом конкретног народа.

1.2. Правило којим се објашњавају облици: в лесу, на берегу или в грязи, на цепи, има се утисак, нимало једноставнијом не чини дату употребу (дати се наставак $-y$ среће код именица мушког рода, углавном једносложних и двосложних, с предлозима 6 и н $a$ у месном или временском значењу; наставак -ѝ се среће код неких именица женског рода треће деклинације с истим предлозима). Ученик може поставити сасвим легитимно питање: а зашто није в дому, на столу, во сну и слично? И наставник тешко да му може дати одговор на ово питање (будући да би морао посегнути за историјом руског језика, што засигурно не само да не би помогло, већ би све још више закопликовало).

Лингвистички предмет, усмерен антропоцентрички, на вишим нивоима учења језика, када се већ овлада основама граматике (другим речима, оним типичним, уобичајеним, регуларним и обавезним у језику), може покушати да понуди некаква објашњења овој, као и многим другим језичким недоумицама.

С овим у вези, рецимо, В. А. Плунгјан, један од водећих руских лингвиста данашњице, типолог по лингвистичком профилу, који је докторирао управо на граматичким категоријама у језицима света, у чланку «К семантике русского локатива («второго предложного» падежа)», објашњење овој појави, маргиналној у савременом руском граматичком систему, налази у постојању семантичке компоненте тешње, јаче, контактне локализације (присутне у виду граматичке категорије у неким дагестанским језицима) - «жесткая локализация» (в грязи, на цепи, в снегу, на ветру...) (Плунгян 2002). Другим речима, на периферији руског деклинацијског система налазе се језичке датости које су директније когнитивно-семантички условљене.

1.3. За потребе овог рада обратићемо пажњу на два национално специфична концепта за руску културу у поређењу са српском: концепт «гриб» и концепт «ягоды».

1.3.1. Когнитивистичка истраживања концепата указују на ограничења с којим се сусрећемо упознајући некакав појам преко речника. За реч гриб наћи ћемо речничко одређење у руским речницима слично оном за реч „гљива“ или „печурка“" у српском.

гриб - низшее растение, не образующее иветков и семян и размножающееся спорами (Ожегов 1990)

Славистика XXII/2 (2018) 
гљива - ниже талусне бесхлорофилне биљке са стабљиком и проширеним горњим делом, клобуком, које саме не стварају органске материје него се хране као сапрофити или паразитски (РМС 1967)

печурка - врста јестиве гљиве с високим и великим шеширом (РМС 1967)

Међутим, за већину говорника руског језика дата реч означава далеко више од наведеног (тачније, већи део наведеног у речничкој дефиницији ни на који начин се човека не тиче у контексту наивне слике света). Како пише Б. Ј. Норман, опис концепта гриб могао би овако да гласи (за Руса): растущзее в осеннем лесу нечто вроде растения, которое человек использует в пищу. Состоит из нож-

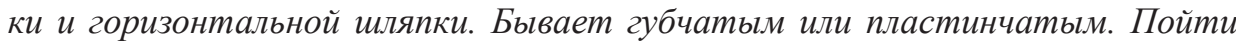
за грибами (по грибы). «Третья охота» (малтене задобија статус «лова»). Корзинка (лукошко) и ножик (прибор за брање). Грибное место (место на коме обично има доста печурака). Грибной дождь (киша након које печурке нагло и брзо ничу). Грибной суп. Отравиться грибами. Ешь пирог с грибами, а держи язык за зубами... Белый гриб, подосиновик, подберезовик, груздь, сыроежка... (неке од најцењенијих руских печурака). Дешевле грибов (в. Норман 2013).

1. 3. 2. Још је 1950. године немачки лингвиста Лео Вајсгербер истакао, између осталог, да језик даје своје виђење стварности и да списак појмова постојећих у стварности и списак појмова који постоје у језику нису истоветни, илуструјући ово речју коров која као појам постоји у свету људи, али не и у природи (в. Вайсгербер 2004). Осим тога, начин категоризације одређених венјезичких ентитета у наивној слици света може се разликовати од категоризације тих истих ентитета у оквиру научне слике света.

Управо ово последње илуструје рад А. Шмељова и Ј. Шмељове „Русская «наивная» ботаника и научная ботаника", у коме аутори указују на значај појма ягода у руској језичкој слици света и скрећу пажњу на неподударност између научне и свакодневне таксономије када су различити плодови биљака у питању. Рецимо, према научној класификацији у једној групи плодова наћи ће се јабуке, крушке и јаребика, у другој - брескве, кајсије и трешња, а у трећој - парадајз, огрозд и боровница. У складу са наивном ботаником, у једну групу (воће) биће сврстане јабуке, крушке, кајсије и брескве, у другу (бобичасто воће) - јаребика, трешња, огрозд и боровница, а парадајз ће се наћи међу поврћем (в. Шмелев, Шмелева 2010). Чињеница да ботаника лубеницу сврстава у исту групу у коју и јаребику веома сликововито илуструје постојање неподударности категоризације ентитета из природе у оквиру наивне слике света са истом из перспективе научно утемељених класификација и категоризација.

С друге стране, далеко већи културолошки значај у руској слици света играју «ягоды» него исти плодови (бобичасто воће) у српској. Примери: собирать ягодbl, пойти за ягодами (по ягодыl); ягодка (у обраћању од милоште); клюква в шоколаде (традиционална посластица), малиновое варенье (и посластица, и народни лек за прехладу), куст рябины (јаребика као симбол руске лепоте, типа српског јоргована). Рябина (рябинушка, рябина кудрявая), калина, малина (калинка, малинка) веома су присутне у руској народној култури (у љубавним песмама, песмама о природи). 
Узимајући у обзир да фразеологизми, по мишљењу В. Н. Телије, представљају својеврсно огледало менталитета одређеног народа а самим тим и његове културно-историјске баштине (Телия 1996), постојање у руском језику фразелогизма того (одного) поля ягода додатно поткрепљује речено, као и неопходност укључивања ширег етно-културног контекста код објашњавања одређених лексичко-семантичких појава (в. Пипер 2014).

1. 4. Да везници-конјунктори могу, осим значења супротстављања, изразити још неко значење, далеко тешње повезано са говорниковим односом према изреченом, сведоче следећи примери:

Он нигде не учил франиузский язык, но знал его прекрасно.

Он нигде не учил франиузский язык, а знал его прекрасно.

Другом реченицом, у којој се супротно значење изражава везником «а», присутна је и говорникова оцена пропозиције као неочекиване.

Употреба супротних везника однако и зато такође захтева узимање у обзир говорниковог става, оцене ситуације као неутралне, негативне/непожељне или позитивне/пожељне.

Оппозиция одобряет проведение переговоров со властью, однако ждет от нее конкретных решений.

Я никогда бы не сдал обычный устный экзамен, зато практические задания выполнял на «отлично».

1.5. Наведени примери, чини нам се, довољно добро илуструју чињеницу да „суво-граматички” приступ познавању и учењу језика, фокусирајући се на правила према којим функционише одређена реч, заборавља на човека који је господар речи и „редитељ” свог говора. Тачније, класична граматика је присуство човека допуштала искључиво у области стилистике, где је одабир овог или оног језичког средства зависио од сфере употребе, ранга и узраста учесника комуникације. Антропоцентрички оријентисане језичке дисциплине, чиме год да се баве (лексиком, творбом речи, морфологијом, синтаксом) не заборављају на модалне језичке аспекте (на она значења која човек својим присуством у језику на овај или онај начин изражава, саопштавајући свој однос према изреченом).

2. На ове и сличне аспекте бављења језиком у руској лингвистичкој науци најтемељније су обратили пажњу припадници тзв. Московске семантичке школе ${ }^{2}$, тј. савремени руски језикословци који се баве тзв. језичком сликом света (осим оних који се убрајају у дату школу, ту су и научници који воде

\footnotetext{
${ }^{2}$ Московска семантичка школа, настала шездесетих година прошлог века под директним утицајем теорије «Смисао↔Текст» И. А. Мељчука и А. К. Жолковског, од 1977. године под руководством је Ј. Д. Апресјана. Почетком осамдесетих година 20. века Ј. Д. Апресјан излаже своју идеју интегралног описа природних језика, која до данас остаје основна каратеристика датог правца у савременој лингвистици и која је своју примену нашла, између осталог, у Активном речнику руског језика (Апресян 2014a, 2014b).
} 
дијалог с њом, корелирају с њом по својим достигнућима: Ана Вежбицка ${ }^{3}$ Н.Д. Арутјунова ${ }^{4}$, J. Н. Караулов 5 и др.).

Теоријско-методолошку основу предмета под називом Човек $у$ огледалу језика у руском и српском језику највећим делом чине радови поменутих аутора, али и савремена научна достигнућа из српске лингвистике упућене на језичку слику света (чији су аутори у великој мери своја научна истраживања темељили на радовима руских аутора), те богата српска традиција конфронтативног проучавања руског језика у поређењу са српским (које је, некад експлицитно, али чешће имплицитно, спонтано, подразумевало поређење двеју језичких слика стварности).

Истраживања оријентисана на језичку слику света (на неке њене делове или на реконструкцију целовите слике), дакле, полазе од становишта да сваки језик одражава начин перцепције и организације стварности (тј. концептуализације). Премда спознајни (когнитивни) механизми човекове перцепције света и употребе језика у свим његовим функцијама јесу универзални, сваки природни језик на свој начин фрагментира свет, формира одређену језичку слику света у виду семантичке мреже појмова, тј. на специфичан начин га концептуализује.

У значајној се мери оваква лингвокултуролошка истраживања ${ }^{6}$ пресецају са оним когнитивистички усмереним ${ }^{7}$, тачније, служе се сличним методама и полазе од сличних начела. Значајно место у оба приступа заузимају испитивања метафоре и метонимије у језику, проучавање концепата, података асоцијативних речника, прототипа и стереотипа.

Антропоцентричко начело у истраживањима језичких феномена иманентна је одлика, поред поменутих, и многих других праваца у савременој лигвистици, тј. оно је крајеугаони камен истраживања српских лингвиста који се баве питањима функционалне граматике, питањима семантике и синтаксе и сл.

\footnotetext{
${ }^{3}$ Ана Вежбицка је, без сваке сумње, једно од најзначајних имена савремене лингвистике, њена теорија семантичких примитива имала је велики утицај на развој микро- и макролингвистике, поготову теоријске семантике у читавом словенском свету (вид. нпр. Вежбицкая 2011). Међу руским лингвистима Вежбицка је веома утицала на рад, између осталих, А.Д. Шмељова, А. А. Зализњак, И. Б. Левонтине, који од Вежбицке преузимају идеју кључних идеја и кључних речи и даље је развијају (вид. нпр. Зализняк и др. 2005).

${ }^{4}$ Н. Д. Арутјунова, истакнути руски лингвиста, аутор монографија «Реченица и њен смисао» (Арутюнова 1976) и «Типови језичког значења: Оцена. Догађај. Факт» (Арутюнова 1988), руководилац пројекта «Логичка анализа језика» (група постоји од 1986. године и разултат њеног рада представља тридесетак томова овог зборника).

${ }_{5}^{5}$ Један од првих аутора који је у руској науци друге половине 20. века обратио пажњу на човека, тј. језичку личност, био је Ј.Н. Караулов, оснивач научне школе «Руска језичка личност». Године 1987. појављује се капитално дело Ј. Н. Караулова «Руски језик и језичка личност» (Карулов 2010), а само годину дана касније под његовим руководством почиње рад на Асоцијативном тезаурусу руског језика.

${ }^{6}$ Веома привлачна и инспиративна за нас је лингвокултурологија (и њена практично конципирана дисциплина која се у руској методици назива лингвострановедение), која се бави узајамним везама културе и језика и утицајем културе на језик (в. радове J. М. Верешчагина и В. Г. Костомарова (Верещагин, Костомаров 1990) и Ј. С. Степанова (Степанов 1997)).

7 Једно од најистакнутијих имена руске когнитивистике, али и теоријске лингвистике, ономасиологије, морфологије и дериватологије, анализе дискурса, свакако јесте име Ј. С. Кубрјакове. Једна од њених 9 монографија носи назив «Језик и знање» (Кубрякова 2004).
} 
2.1. Даље у раду споменућемо имена само неких од аутора који су кључно допринели развоју антропоцентричких истраживања у домаћој науци о језику.

Свака лингвистика има своје корифеје, оне који неко зрно лингвистичке мисли умеју у правом тренутку да посаде, правилно негују, па се то зрно не само разбокори и буде плодоносно, већ изроди многе младице које потом и саме ојачају. Један од таквих корифеја српске лингвистике свакако јесте академик Милка Ивић. Језикословно богатство проф. Ивић садржи радове и из области когнитивне лигвистике који су, између осталог, сабрани и систематизовани у три тома њених Лингвистичких огледа (Ivić 1983, 1995, 1999). Прва два тома представљају наше врло важно теоријско-методолошко упориште у погледу граматичке и лексичке семантике, док се на примеру радова који су ушли у трећи том, у ком М. Ивић називе за боје посаматра и из аспекта њихове еволуције (њихове етимологије, значења и употребе у савременом језику) илуструју промене до којих долази и/или може доћи у концептуализацији одређених сегмената реалности као резултата спознајне и социјалне делатности човека.

2.2. Простор је поред времена једна од основних појмовних категорија, а теорије о спацијалној природи непросторних значења данас имају своју доста дугу и богату историју, која има важно место у оквиру предмета Човек $y$ огледалу језика у руском и српском. Монографија академика Предрага Пипера Zamenički prilozi: (gramatički status i semantički tipovi) у време када се појавила представљала је значајан искорак у савременој лингвистичкој мисли у нас: аутор у њој даје најважније појмове своје концепције локалистичке теорије (коју ће потом изложити и у књизи Језик и простор (Piper 1997).

2.3. Врло важни елементи појмовног и терминолошког апарата когнитивног подсистема лингвокултурологије јесу 'прототип’ и 'стереотип'. Управо због тога у списак обавезне литературе за предмет Човек у огледалу језика у руском и српском улази и монографија Језичка слика стварности: когнитивни аспект контрастивне анализе Људмиле Поповић(Поповић 2008). Дата монографијау тренутку свог појављивања не само што је представљала најобимније и најтемељније истраживање из области језичке слике света код нас, већ се издвајала и својом иновативношћу, између осталог, ауторским дефиницијама појмова 'прототипа' и 'стеротипа', док друга монографија Љ. Поповић, која носи назвив Контрастивна граматика српског и украјинског језика: таксис и евиденцијалност, представља битну теоријско-емпиријску подлошку за упознавање студената са функционално-семантичким категоријама таксиса и евиденцијалности (Поповић 2014).

2.4. Посебно место у литератури за предмет Човек у огледају језика у руском и српском заузимају књиге и чланци Ксеније Кончаревић, која је међу првима код нас почела да објављује лингвокултуролошки усмерене радове и која је, без сваке сумње, родоначелник не просто антропоцентрички устројене, већ теоантропоцентрички устројене лингвистичке мисли у нас (вид. нпр. Кончаревић 2006; 2011; 2013; 2014). Захваљујући радовима К. Кончаревић, наши студенти могу да се упознају са развојем теолингвистике као самосталне лингвистичке дисциплине, са основним одликама богословских текстова, проблемима превода, стилистике, лексикологије, лексикографије, граматичке и лексичке семантике, питањима језичке комуникације и сл. из аспекта теолингвистике.

Славистика XXII/2 (2018) 
2.5. Када је пак реч о концептуалној анализи српске лексике (у поређењу с руском) врло важан теоријско-емпиријски извор за нас и наше студенте представља једна од пионирских монографија посвећених овој проблематици, а чији су аутори Стана Ристић и Милана Радић-Дугоњић. Њихова књига Реч. Смисао. Сазнање (Студија из лексичке семантике), као продукт удружене лингвистичке мисли и знања из области лексичке семантике и когнитивне лингвистике, представља, с једне стране, сјајан теоријско-методолошки предложакза самостална истраживања наших студената, а са друге стране, одличну илустрацију предности тимског рада који је у нашој лингвистици недовољно заступљен (Ристић и др. 1999).

2.6. У овом делу рада поменули смо само неке од аутора чија постигнућа из области антропоцентрички оријентисаних лингвистичких дисциплина (функционалне граматике, когнитивне лингвистике, лингвокултурологије и сл.) чине теоријскометодолошку основу предмета Човек у огледалу језика у руском и српском.

Поред наведених аутора у списак обавезне литературе улазе радови многих наших лингвиста. Тако, узимајући у обзир важност методе анализе вербалних асоцијација као изузетно погодне за уочавање и анализу утицаја културних и друштвених промена на значење лексема, у тај списак улазе радови Р. Драгићевић (нпр. Драгићевић 2010), М. Стефановић (нпр. Стефановић 2012).

Метафора је онтолошка особина когнитивне делатности човека, она представља један од начина стварања језичке слике света. Стога механизми метафоризације и метафоричке концептуализације јесу једна од врло важних тема које се обрађују у оквиру предмета који се у овом раду представља, а приликом обраде дате теме радови Д. Кликовац (нпр. Klikovac 2004) свакако представљају неизоставну литературу.

Наравно, на овоме се списак аутора чија су научна истраживања инкорпорирана у теоријско-методолошки оквир обликовања предмета Човек у огледалу језика у руском и српском не завршава, будући да би у оквиру оваквог једног рада тешко било могуће дати потпуни преглед свих релевантних извора.

3. Из свега до сада поменутог чини нам се да је антропоцентричност довољно убедљива, присутна, привлачна и ефикасна научна парадигма која је створила повољне услове за бављење језичком сликом света. Научна парадигма, која је на снази и у домаћој лингвистици, такође представља значајан подстрек за конституисање оваквог једног изборног предмета.

Студент би, према замисли извођача, требало да овлада основним појмовима битним за руску језичку слику света, да научи да уочава различиту или сличну концептуализацију појмова у руској и српској култури. Оваква практична и теоријска професионална компетенција боље ће му помоћи да разуме руске културне концепте, што, са друге стране, утиче позитивно и на развој и сигурност и у језичкој компетенцији. Померање акцента са граматике, са правила на обичај, употребу, конотације, уверени смо у то, игра и веома позитивну мотивациону улогу у учењу језика. Уочавање сличног или различитог у језичкој слици света у страном језику у поређењу са матерњим такође утиче позитивно на грађење сопственог личносног и националног идентитета. 


\section{Цитирана литература}

Апресян, Юрий Д. Избранные труды. Т. ІІ. Интегральное описание языка и системная лексикография. Москва: «Языки русской культуры», 1995.

Апресян, Юрий Д. Активный словарь русского языка. Т. 1. А-Б. Отв. ред. акад. Ю. Д. Апресян. Москва: Языки славянской культуры, 2014a.

Апресян, Юрий Д. Активный словарь русского языка. Т. 2. В-Г. Отв. ред. акад. Ю. Д. Апресян. Москва: Языки славянской культуры, 2014b.

Арутюнова, Нина Д. Предложение и его смысл. Логико-семантические проблемы. Москва: Наука, 1976.

Арутюнова, Нина Д. Типы языковых значений: Оценка. Событие. Факт. Москва: Наука, 1988.

Арутюнова Нина Д. Язык и мир человека. Москва: Языки русской культуры, 1999.

Вайсгербер, Йохан Л. Родной язык и формирование духа. Пер. с нем., вступ. ст. и коммент. О.А. Радченко. Москва: Едиториал УРСС, 2004.

Вежбицкая, Анна. Семантические универсалии и базисные концепты. Москва: Языки славянских культур, 2011.

Верещагин, Евгений М., Виталий Г. Костомаров. Язык и культура: Лингвострановедение в преподавании русского языка как иностранного. Изд. 4-е. Москва: Русский язык, 1990.

Драгићевић, Рајна. Вербалне асоцијације кроз српски језик и културу. Београд: Друштво за српски језик и књижевност, 2010.

Зализняк, Анна А., Ирина Б. Левонтина, Алексей Д. Шмелев. Ключевые идеи руссской языковой картины мира. Москва: Языки славянской культуры, 2005.

Караулов, Юрий Н. Русский язык и языковая личность. Москва: ЛКИ, 2010.

Кончаревић, Ксенија. Језик и православна духовност. Студије из лингвистике и теологије језика. Крагујевац: Каленић, 2006.

Кончаревић, Ксенија. Руски језик у теологији: обликовање теолошког текста, техника превођења. Београд: Православни богословски факултет, 2011.

Кончаревић, Ксенија. Сакрална комуникација: норме, традиције, средства. Београд: Православни богословски факултет, 2013.

Кончаревић, Ксенија. Руски језик у комуникацији и мисији Цркве: функционални стилови, ресурси, жанрови. Београд: Православни богословски факултет, 2014.

Кубрякова, Елена С. «Эволюция лингвистических идей во второй половине ХХ века (опыт парадигмального анализа)». [В:] Язык и наука конца 20 века. Под ред. ак. Ю. С. Степанова. Москва: Институт языкознания РАН, 1995: 144-238.

Кубрякова, Елена С. Язык и знание: на пути получения знаний. Москва: Языки славянской культуры, 2004.

Норман, Борис Ю. Когнитивный синтаксис русского языка. Москва: Флинта. Наука, 2013.

Ожегов, Сергей И. Толковый словарь русского языка. Москва, 1990.

Пипер, Предраг. Лингвистичка русистика. Београд: Славистичко друштво Србије, 2014.

Плунгян, Владимир А. «К семантике русского локатива („второго предложного” падежа)». Семиотика и информатика. 37, 2002: 229-254.

Поповић, Људмила. Језичка слика стварности. Когнитивни аспект контрастивне анализе. Београд: Филолошки факултет, 2008.

Славистика XXII/2 (2018) 
Поповић, Људмила. Контрастивна граматика српског и украјинског језика: таксис и евиденцијалност. Београд: САНУ, 2014.

PMC: Речник српскохрватскога књижевног језика I-VI. Нови Сад - Загред: Матица Српска - Матица Хрватска, 1967.

Ристић, Стана, Милана Радић-Дугоњић. Реч. Смисао. Сазнање (студија из лексичке семантике). Београд: Филолошки факултет, 1999.

Степанов, Юрий С. Константы. Словарь русской культуры. Опыт исследования. Москва: Школа «Языки русской культуры», 1997.

Стефановић, Марија. Језичка слика породице у руском и српском језику. Нови Сад: Филозофски факултет, 2012.

Телия, Валентина Н. Русская фразеология. Москва: Школа «Языки русской культуры», 1996.

Толстая, Татьяна. Легкие миры. Retrieved January 14. 2018/ From https://www. litmir.me/br/?b=214412\&p=1/, 2014.

Шмелев, Алексей Д. Русская языковая модель мира: Опыт словаря. Москва: Языки славянской культуры, 2002.

Шмелев, Алексей Д., Елена Я. Шмелева. «Русская „наивная” ботаника и научная ботаника». Учительская газета. 43. Retrieved January 14, 2018. From $<$ http://www.ug.ru/archive/37376>, 2010.

Яковлева, Екатерина С. Фрагменты русской языковой картины мира (модели пространства, времени и восприятия). Москва: Гнозис, 1994.

Ivić, Milka. Lingvistički ogledi. Beograd: Slovograf, 1983.

Ivić, Milka. O zelenom konju. Novi lingvistički ogledi. Beograd: Slovograf, 1995.

Ivić, Milka. Lingvistički ogledi, tri. Beograd: XX vek, 1999.

Klikovac, Duška. Metafore u mišljenju i jeziku. Beograd: XX vek, 2004.

Piper, Predrag. Jezik i prostor. Beograd: XX vek, 1997.

Биляна Марич, Драгана Керкез

\section{ЧЕЛОВЕК В ЗЕРКАЛЕ ЯЗЫКА В РУССКОМ И СЕРБСКОМ: НОВЫЙ ФАКУЛЬТАТИВНЫЙ ПРЕДМЕТ НА КАФЕДРЕ СЛАВИСТИКИ}

\section{Резюме}

В статье предлагается теоретическое и практическое обоснование нового факультатива на кафедре славистики филологического факультета Университета в Белграде, ориентированного на антропоцентрические лингвистические парадигмы, на исследование «языковой картины мира».

На конкретных примерах из словообразования, морфологии, лексики и синтаксиса иллюстрируется потребность в таком подходе к изучению языка (в основном на высших уровнях образования). Авторы находят опору в своем подходе и в сопоставительных исследованиях русского и сербского языков в нашей среде.

Предполагается, что предмет с методического аспекта сыграет положительную мотивационную роль, поможет лучше понять «свое» в контексте «чужого».

Ключевые слова: антропоцентризм, лингвистика, языковая картина мира, факультативный предмет, русский язык, сербский язык. 